\title{
Ethnic and Civic Conceptions of the Nation in Ukraine's History Textbooks
}

Abstract: This article examines how the Ukrainian nation is portrayed in the history textbooks of contemporary Ukraine. It will argue that the textbooks conceive the core of Ukrainian national identity in ethnic terms as they singly out language as the constituent bearer of Ukrainian nationhood. Yet, civic conceptions are also advanced as national loyalties are said to be contingent on current social issues. It further observes that the textbooks unanimously condemn foreign rulers and their legacy in Ukraine. The textbooks also tend to have negative appraisals of the non-Ukrainian minorities, although these appraisals grow more neutral over time (with the exception of those dealing with the Russian minority). It will be argued that the account of history as laid down in the textbooks is primarily motivated by a desire to justify Ukrainian statehood. This desire, it is claimed, was conducive for a vision of the Ukrainian nation that maximizes cultural distinctiveness vis-à-vis Russia as opposed to a more inclusive vision that would incorporate Ukraine's Russians.

\section{Introduction}

This article examines the image of the Ukrainian nation in the history textbooks of postSoviet Ukraine. Ukraine is an interesting case as it is the second most populous Soviet successor state - 48 million inhabitants according to the 2001 census - and harbours a population with a complicated ethno-linguistic structure. This demographic portrait differs from that of other post-Soviet states in that a substantial part of the titular nation (ethnic Ukrainians) has become Russified during the Soviet era. Consequently, ethnic and linguistic cleavages do not coincide: whereas ethnic Ukrainians and ethnic Russians make up 78\% and 
$18 \%$ of the population respectively, the Ukrainian- and Russian-speaking communities constitute roughly equal halves. ${ }^{1}$ The question is how the authorities are trying to carve a unifying national identity out of this potentially divisive Soviet legacy. The analysis focuses on history textbooks as history provides the architects of nation-building with an almost infinite source of raw material from which historical myths and narratives can be extracted that underpin and justify a nationalist discourse. Selection and interpretation of events are the key activities in this process. The use of history in schools, moreover, has the capacity to exert a powerful influence over both individual and collective minds (Phillips 1998).

Our primary concern is with the nature of the Ukrainian nation being portrayed in the textbooks. Is this nation conceived of in exclusionary/ethnic or inclusive/civic terms? The Ukrainian authorities may be said to be faced with a real dilemma in choosing between one of these visions as both have important drawbacks. Thus, an ethno-cultural conception of nationhood stressing Ukrainian language and descent has maximum distinctive potential but it runs the risk of alienating the non-Ukrainian(-speaking) groups in the population. On the other hand, an inclusive multicultural vision of the nation may accommodate all ethnolinguistic groups but it fuels fears of continuing Russification among Ukrainian-speakers and fails to provide markers that can distinguish a Ukrainian national identity from a Russian one.

First, we will examine the origins of the ethnic-civic dichotomy and explain how it can be related to the analysis of textbooks. The second and third sections discuss indications of civic and ethnic visions of the nation, respectively. The last section summarizes and interprets the main findings and offers some tentative predictions.

\section{The history of the ethnic-civic framework}


The distinction between civic and ethnic notions of nationhood has a long tradition in the social sciences. It can be traced back to the polemic at the end of the $18^{\text {th }}$ century between the French rationalists, represented among others by Jean-Jacques Rousseau, and the German romanticists, personified by the philosopher Johann Gottfried Herder (Wiborg 2000). The former asserted that the nation is the product of a set of conscious choices made by individuals who believe it is in their best interest to participate in a larger political community. The French rationalists thus underlined the open, voluntary and calculated nature of national membership. For them the nation was a modern political community that could not be seen separately from state institutions as these represented the values and interests of individual citizens - hence the notion of popular sovereignty - and offered the citizenry a distinct mix of benefits and obligations. As individual preferences differed, the nation and its political institutions were a constant battleground of conflicting interest groups. The nation was also perceived to be contingent on contemporary socio-economic issues given that individuals constantly adjusted their cost-benefit appraisals of national belonging to changed circumstances. In short, the nation to the French rationalist was a dynamic, heterogeneous political community with porous borders, a product of deliberate human agency.

The German romanticist completely opposed this view. They saw the nation as a natural entity with deep roots in the past. Membership of the nation was not based on rational calculation but on the emotional need of individuals to belong to a wider cultural community. National political institutions above all expressed the collective harmonious will of the nation instead of conflicting individual interests. Moreover, the ties that were said to bind individuals to the nation (ancestry, native language, traditions, religion) were judged to be of an immaterial, cultural and above all permanent nature. As a result the boundaries and characters of nations were fixed and highly resistant to the social pressures of the day, the 
romanticists argued. In sum, the nation was a closed, homogeneous and permanent entity, one of the givens of nature unaffected by conscious human action.

Later several scholars have elaborated on the ethnic-civic distinction. In his famous Weltbuergertum und Nationalstaat (published in 1907), the German historian Friedrich Meincke (1970), for instance, distinguishes between a Kulturnation and a Staatsnation. The historian most associated with the ethnic-civic framework however was Hans Kohn. He first of all introduced a regional dimension to the distinction by contending that the popular sovereignty (or civic) idea of the nation only prevailed in countries with strong middle classes (i.e. in United States, Great Britain, France, Switzerland and The Netherlands). In the peripheral states of Western Europe, in the German-speaking countries and in Eastern Europe the ethnic vision became the dominant mode of understanding nationhood (Kohn 1944; 1962; 1994). Yet, what made his works particularly famous and controversial at the same time was that he added a normative component to the ethnic-civic distinction. He expressed a clear preference for the civic vision of the nation seeing that as the sole variety of nationalism compatible with pluralism, democracy and human rights. Ethnic nationalism in his view was the logical companion of authoritarianism and intolerance towards ethnic others.

The civic-West/ethnic-East model introduced by Kohn has both inspired many scholars and attracted a great deal of criticism (for good overviews of scholars critical of various aspects of the framework see Kuzio (2002) and Shulman (2002). I confine myself here to the criticism on the regional dimension as that is the most relevant from the perspective of this study. Many authors have attacked this dimension saying that it is absurd to conceive of the framework as a crude dichotomy neatly separating ethnic Eastern from civic Western states. Instead, they argue, the model should be seen as an ideal-typical distinction with all nations exhibiting both ethnic and civic features in various proportions. Smith $(1991 ; 1998)$ for instance asserts that all modern nations, including Western ones, rest on strong ethnic 
foundations, although he does attribute state nationalist traditions to some nations and nationalisms grounded in vernacular cultures to others. Kuzio $(2001 ; 2002)$ has taken Smith's argument one-step further by contending that many Western states have evolved from ethnic to civic states. He relates the proportional mix of civic and ethnic practises in a given state to the age of that state and to its ability to consolidate democracy - i.e. the younger the state and the more infant its democratic institutions, the less opportunity it had to develop civic structures and the more ethnic it still is (Kuzio 2002). This sharply contrasts with Kohn's view that the ethnic or civic character of a nation is regionally determined.

Now how do these arguments relate to our study of textbooks? They are relevant for this study in a sense that they all predict different outcomes. If the textbooks display a clear and continuous preference for ethnic understandings of nationhood, Kohn's ethnic-civic framework is confirmed. If they start out by promulgating strong ethnic visions but gradually adopt more civic understandings, Kuzio's developmental model would appear to have most explanatory power.

The next question that commands our attention is how the terms civic and ethnic can be operationalized; how can we determine whether the textbooks present a civic or an ethnic understanding of nationhood? I distilled four indicators from the theory discussed above: (1) the ratio of modern to pre-modern history in the national history course; (2) the degree of attention given to social issues and matters of political representation and their intersection with the national question; (3) the evaluation of the contribution of ethnic others and foreign regimes to Ukrainian society, and (4) the degree of interest in language, descent and other cultural markers. I will assert that the textbooks present a civic understanding of the nation if the majority of them deal with modern history (i.e. from 1800 to the present), and if they highlight social issues and cleavages, especially those within the titular ethnic group. I will 
further regard positive appraisals of ethnic others (Russians, Poles, Jews) and foreign regimes, and minimal attention devoted to cultural issues as instances of civic conceptions. By contrast, an emphasis on the pre-modern period, on cultural matters instead of social ones, and a narrative discrediting national minorities and all things foreign are interpreted as manifestations of an ethnic vision of the nation.

\section{The Ukrainian school system and history education}

Before examining the textbooks a brief word must be said about the Ukrainian school system and the place of history education in the school curricula. As it turns out, no major structural reforms have occurred in this branch of the education sector since independence. Schools have therefore retained the characteristics of the Soviet school system. They are by and large state-owned and state-governed, combine primary and secondary education, and offer nonselective comprehensive education until upper secondary. Particularly the centralized nature of the school system stands out: as in the Soviet days the Ministry of Education exerts full control over the content, volume and level of education. ${ }^{2}$ This extends to the level of textbooks. For every school subject the Ministry announces regular textbook competitions, the winners of which are subjected to a complex procedure of reviewing, testing and revision. Only after receiving an official stamp of approval from the Ministry are these books permitted for use in schools across Ukraine (Popson 2001; Janmaat 2002).

The Ministry split history education in schools up into two subjects - History of Ukraine and World History. The institution of a separate course on national history is indicative of the importance assigned to the subject in promoting national identity. This is also underlined by statements in the curriculum plans for national history. The 1996 plan, for 
instance, asserts that one of the course's objectives is to "educate pupils in a patriotic spirit so that they cultivate a love for their nation" (Prohramy (...) Klasy 1996, p. 9). Another sign of the primacy accorded to national history is the fact that the first generation of textbooks dealing specifically with history of Ukraine appeared as early as 1993, in spite of huge problems facing both textbook writers and the Ministry. Textbook authors for instance had to cope with the complete absence of sources on Ukrainian history as a result of 70 years of Soviet censorship.

This study analyzes the textbooks for the History of Ukraine course. As noted before it will compare two generations of textbooks to explore the dynamics of school history writing. I will examine the following books of the first generation (appearing in 1993-1996):

- Grades 7-8: H.Y. Serhienko and V.A. Smolyi (1985). A history of Ukraine from ancient times to the end of the eighteenth century.

- Grade 9: V.H. Sarbei (1996). A history of Ukraine of the nineteenth and the beginning of the twentieth centuries.

- Grade 10: F.H. Turchenko (1994). A history of Ukraine from 1917 to 1945.

- Grade 11: F.H. Turchenko, P.P. Panchenko and C.M. Tymchenko (1995). A history of Ukraine from 1945 to 1995.

Of the generation currently in use the following textbooks will be analysed: ${ }^{3}$

- Grade 8: H.K. Shvyd'ko (2003). A history of Ukraine from the beginning of the sixteenth to the end of the eighteenth century.

- Grade 9: F.H. Turchenko and V.M. Moroko (2001). A history of Ukraine from the end of the eighteenth century to the beginning of the twentieth century. 
- Grade 10: F.H. Turchenko (2001). A history of Ukraine from 1914 to 1939.

- Grade 10: S.V. Kul'chyts'kyi and Y.I. Shapoval (2003). A history of Ukraine from 1914 to 1939.

- Grade 11: F.H. Turchenko, P.P. Panchenko and C.M. Tymchenko (2001). A history of Ukraine from 1939-2001.

All the textbooks examined in this study have received the Ministry's stamp of approval. For most grades the Ministry currently offers schools a limited choice of two to four official textbooks. Grade nine however only has one official textbook. ${ }^{4}$ The authorized status of the textbooks means that they are promoted and widely distributed in schools throughout Ukraine. They are therefore likely to have a significant impact on the historical opinions and national identity of a whole new generation of Ukrainians. This makes history textbooks a particularly interesting object of study for the student of Ukrainian nation-building policies.

\section{Civic visions of the Ukrainian nation: an emphasis on modern history and social issues}

A study of the history curriculum plan reveals that pupils are first acquainted with history of Ukraine at age 10 in the fifth grade. ${ }^{5}$ The course for this grade offers a birds-eye view of history of Ukraine from prehistoric times to the present. As 75 per cent of the curriculum plan and the corresponding textbook cover the period up to the 1800 s, the emphasis is clearly on pre-modern times. Yet, this ratio is reversed in the main course of history of Ukraine, which runs from the seventh to the eleventh grade. Whereas only grades seven (ancient history to the $16^{\text {th }}$ century) and eight ( $16^{\text {th }}$ to $18^{\text {th }}$ century) deal with the pre-modern period, grades nine ( $19^{\text {th }}$ century and early $20^{\text {th }}$ century), ten (1914-1939) and eleven (1939 to present) all cover 
the modern times. Moreover, the number of hours doubles from 34 annually in both grade seven and eight to 68 annually in both grade nine and ten. In grade eleven 51 hours are devoted to the subject. As the main course is far more important than the introductory course of the fifth grade, one may safely conclude that the central curriculum gravitates to the modern period.

Let us now turn to the textbooks themselves and examine to what extent they address socio-political issues and their intertwinement with ethnicity. As it turns out, class struggle is a key theme in all the books. Unanimously, both generations of textbooks equate the Ukrainian nation with the class of landless peasants, claiming that the latter have suffered from centuries of serfdom and exploitation by (foreign) nobles and have waged a protracted struggle to free themselves from social and foreign oppression. Remarkably, they do not confine their social criticism to the Polish nobility and other foreign nobles with possessions in Ukraine. For instance, the books dealing with the Cossack Free state of the $17^{\text {th }}$ century do not idealize the social conditions prevailing in Cossack society. Although they see the Cossack state as an important manifestation of early Ukrainian statehood and depict its guardians the Cossacks (free farmer-soldiers who had fled serfdom) as true Ukrainian freedom fighters, they point out that the ideal of establishing an egalitarian society of free farmers not subordinated to landlords of whatever origin was quickly abandoned. Thus, Serhienko and Smolyi (1995) accuse the Cossack higher circles (the so-called starshyna) of enriching themselves at the expense of the lower classes by taking much of their lands and increasing their labour duties. Interestingly, in doing so they avail themselves of a terminology that can typically be associated with a Soviet account of history: "workers", "toiling masses", "social oppression”, "social struggle of the labouring masses" (ibid. pp. 183, 195, 236). As both authors also wrote textbooks in Soviet times, they may have found it difficult to find words appropriate for the changed historical narrative (Janmaat 2002). In 
perhaps slightly milder terms, Shvyd'ko (2003, p. 205), the author of the new textbook, is also critical of the social developments in Cossack society: "In the eighteenth century the Cossack class largely lost its character of a free group of people not dependent on anyone, the idea that had attracted so many peasants and townsmen. (...) After the war in conditions of general turmoil a part of the peasantry increasingly lost land and became landless peasants. Peasants were forced to do labour duties on private estates." Yet, despite having to pay taxes to the tsarist treasury and perform labour duties, the peasants had freedom of movement and were therefore genuinely free men, Shvyd'ko argues. The significance of these extracts lies in the acknowledgement of the existence of sharp social cleavages and conflicting interests within the ethnic Ukrainian group. This runs counter to an ethno-national interpretation of history that sees the Ukrainian nation as an 'innocent' internally harmonious community oppressed by 'malign' foreign regimes.

Social problems and issues of political representation also make up an important part of the discussion of the turbulent years following the February revolution in 1917. The books covering this period all address the complex relationships between social class (urban workforce, peasantry and bourgeoisie) and loyalty to the Central Rada (the parliament of the short-lived Ukrainian National Republic), the Bolsheviks or the Whites. The books all agree that parallel to the February and October revolutions a genuine national revolution occurred in Ukraine and that the political force resulting from that, the Central Rada, was the only body legitimately representing the Ukrainian population. The 1995 edition of Turchenko, for instance, claims that the Ukrainian nationalist parties captured 75 per cent of the vote while the Bolsheviks received only 10 per cent in the elections in Ukraine for the newly created allRussian council, implying that support for the national cause was much stronger than for the revolutionary message of the Bolsheviks. But at the same time all books contend that the Central Rada had difficulty in securing the loyalty of the poorer sections of the peasantry 
because it did not decisively act on the crucial issue of land reform. In this regard it is interesting to note that both editions of Turchenko (1995, p. 41; 2001, p. 79) quote the historian Viacheslav Lypinsks'kyi who "with bitterness stated that the 'notion of Ukraine' ... was replaced by the notion of the 'desiatina zemli' [a specific measure of land; this refers to the heated debate waged at the time on whether estates of less than 40 desiatina would be subject to redistribution as well, JGJ]. They thus concede that a Ukrainian national consciousness was quite shallow among the peasantry and that the national idea unsuccessfully competed with the social problematic of land reform. In similar vein, all three books assert that the uncompromising rhetoric of the Bolsheviks was much more appealing to large sections of the working class and the peasantry than the liberal-nationalist message from the Central Rada in the turbulent times of the revolution and its aftermath:

The message of an immediate expropriation of the properties of landlords and capitalists and the promise of a socialist society allured the urban and rural poor, which constituted almost a third of Ukraine's population (Turchenko 2001, p. 79).

The democratic-liberal forces that were unleashed by the revolution tried to convince the population that it was necessary to found state institutions and begin constituting assemblies. However, after the collapse of the autocratic regime anarchy spread like wildfire in the country. The war continued, swallowing human and material resources, and the economic situation deteriorated from month to month. Anger, despair and a hostile attitude towards the ruling classes grew steadily among the lower classes. The Russian Revolution had begun and developed under the slogans 'peace to the people', 'land to the peasants', 'factories to the workers'. Not having any experience with living in a democratic society, the proletarian masses only took part in their own class organizations - soviets, professional syndicates and employees councils (Kul'chyts'kyi and Shapoval 2003, pp. 35,36). 
The books also concede that the Russian-speaking urban proletariat in the industrial Donbass region backed the Bolsheviks from the start. However, they are never tired of reminding the reader that only a minority of the total population supported the Bolsheviks. All three books for instance mention the 'All-Ukrainian' assembly of soviets that the Bolsheviks convened in Kharkiv in December 1917 as an alternative to the Central Rada in Kyiv. They point out that both councils claimed to be the true parliament of the Ukrainian National Republic and that the hostility between the two eventually led to open warfare and to the invasion of the Red Army in Ukraine. But the Kharkiv assembly, the authors contend, attracted delegates of no more than one-third of the Ukrainian local soviets and hosted very few representatives of the peasantry, which comprised the vast majority of the population. Therefore, the Bolsheviks could not possibly claim to be the legitimate representative of the Ukrainian population, it is argued. The prevailing narrative of the textbooks is thus that the arrival of Bolshevik power in Ukraine was due to exceptional circumstances and the use of force but in no way reflected the will of the people. In this regard, it must be noted that the editions of Turchenko are decidedly more radical in tone than Kul'chyts'kyi and Shapoval. Both editions for instance end a section with a strong condemnation: "The establishment of Bolshevik power in Ukraine, by means of deceit, violence and direct interference from abroad, inevitably had to become and became the object of nationwide opposition" (Turchenko 1995, p. 58; 2001, p. 97). However, despite their unanimous rejection of the Bolshevik regime, it is revealing that all three books emphasize sharp social cleavages within Ukrainian society, cleavages moreover that are said to affect both Ukrainian national consciousness and the loyalty of ethnic Ukrainians to the Central Rada, the institution claiming to represent the Ukrainian nation. This, we might argue, constitutes an implicit endorsement of a contingent, pluralist and therefore civic interpretation of the Ukrainian nation. 
Ethno-cultural visions of the nation: language as the defining element and a negative evaluation of foreign regimes and ethnic others

Characterizations of the Ukrainian nation provide direct clues of how this nation is visualised in the textbooks-as a culturally homogenous unit comprising only ethnic Ukrainians or as a multicultural entity shaped by political events and including Russian, Jewish, Crimean Tatar and Polish minorities. The textbooks turn out to express a clear preference for an ethnocultural understanding of the nation. The first generation textbook for the ninth grade is most outspoken. It sees the peasantry as "the most stable bearer and protector of the ethnic qualities of the Ukrainian people" and argues that native language was the single most important marker binding the Ukrainians living in the Austro-Hungarian part of Ukraine to those residing in czarist Ukraine: "The cementing force unifying the national culture was the Ukrainian language (...) Only together did they [the Ukrainians living Austria Hungary and czarist Russia, JGJ] constitute a unified Ukrainian nation, membership of whom was above all determined by native language" (Sarbei 1995, pp. 104, 106, 107).

A penchant for an ethnic understanding of nationhood also permeates the old and new editions of Turchenko's $(1995 ; 2001)$ textbook for the tenth grade. Both books begin the narrative on the $20^{\text {th }}$ century by presenting a map showing the residential territory of ethnic Ukrainians and the state borders of the time. This territory is not given modest dimensions as it not only includes the regions in Austria Hungary and czarist Russia comprising the whole of present-day Ukraine but also areas located in contemporary Poland and Russia. Drawn in this way, the map may be said to carry two important hidden messages. First it tells the reader that the Ukrainian nation has retained its cultural traits and national consciousness despite being ruled by foreign powers. Second, and perhaps more importantly, it communicates that 
all of the current state territory is native Ukrainian soil and that Ukraine is actually entitled to more on the basis of the residential pattern of ethnic Ukrainians. The books, however, acknowledge that the Ukrainian lands harboured a multinational population. They state, for instance, that Jewish and Russian minorities dominated the cities of Russia-held Ukraine, and turned these cities into Russian-speaking islands surrounded by a Ukrainian-speaking countryside. The same is said to be the case in Austria-held Ukraine where Poles, Austrians and Jews were the urban dwellers and German and Polish the languages spoken in the cities. One might argue that the emphasis on the urban-rural divide in the residential pattern of ethnic Ukrainians and national minorities actually reinforces the map's covert meaning that the area inhabited by ethnic Ukrainians is the land where they constitute the native population, and thus the territory over which Ukrainians can exert a 'legitimate' political claim.

The preponderance of ethno-cultural understandings is further underlined by the ample attention given to the development of the Ukrainian language and culture under foreign domination. All books highlight the attempts by successive foreign regimes to suppress the Ukrainian language, efforts which are interpreted as being closely connected to the Ukrainian national question. Thus, both the old and the new book for the ninth grade contend that the $19^{\text {th }}$ century czarist bans on Ukrainian-language textbooks, education, literature, theatre plays and songs represented a deliberate policy of obstructing the awakening of the Ukrainian nation (Sarbei 1994; Turchenko and Moroko 2001). Similarly, The textbooks for the $11^{\text {th }}$ grade understand the russification measures of the $1970 \mathrm{~s}$ and 1980s as the principle expression of the official Soviet policy of the sblizhenie (drawing together) and eventually sliianie (merger) of Soviet nationalities into the Russian-speaking Soviet nation (Turchenko, Panchenko and Tymchenko 1995; 2001).

The second indicator of the kind of nation communicated is the evaluation of the attitudes and contributions of foreign rulers and national minorities to Ukrainian society. It 
appears that these attitudes and contributions, particularly those of foreign regimes, are almost all appreciated negatively. Thus, the books are in solid agreement that czarist Russia, Poland and Austria tried to maintain exploitative landowner-peasant relationships, turn Ukraine into a colony with a dependent economy and deny the existence of the Ukrainian nation. Consider, for instance, the tone of the new book for the ninth grade when it discusses the economic policies of czarist Russia in Ukraine: "The leading principle of the Russian government in developing the non-Russian region of the Empire, including Ukraine, was the interest of the empire. As a consequence, only those branches of industry arose in Ukraine for which the natural conditions in Russia were not suitable (e.g. sugar industry), or those that supplied the Russian industry with raw materials and semi-manufactured materials (steel and coal industry)" (Turchenko and Moroko 2001, p. 156). In similar vein, Kul'chytsk'kyi and Shapoval' (2003, pp. 273,274) are highly critical of the Polish government in the interwar period, accusing it of trying to forcefully polonise the West-Ukrainian lands and its people by a variety of measures:

The internal polities of Poland were aimed at the 'swallowing up' of lands with a predominantly non-polish population. This swallowing up was conceived of as a process with different stages. First came state integration, later ethnic assimilation. State colonisation meant the submission of the non-Polish population to the institutions, duties and rights that existed elsewhere in Poland, and the expulsion of community life to the periphery or the complete liquidation of organisations founded by Ukrainians in the years before the collapse of the Austro-Hungarian Empire. Ethnic polonisation was planned as a long-term process targeting first of all children. (...) What most of all strained ethnic relations in Poland, however, was the settlement policy, which involved establishing a true 'fifth column' in Western Ukraine, the so-called settlers. 
This is not to say that all actions of foreign rulers are discredited. Some policies are appreciated as having contributed to the socio-economic development of Ukraine. However, in each single case, the books mitigate these positive contributions by arguing that they were largely ineffective or served other interests than those of the Ukrainians themselves. The account of the abolition of serfdom in 1861 by Czar Alexander II is a case in point. Both Sarbei (1995) and Turchenko and Moroko (2001) acknowledge that this reform constituted a major step forward, freeing serfs from their landlords, offering them freedom of movement and allowing them to buy land and goods and engage in commercial activities. Yet, both authors are quick to point out that the reform was designed from above by the landowning nobility and therefore primarily served the interests of the landowners. They also observe that the reform did not improve the living conditions of the vast majority of peasants, crippled as these rural masses were by rents and some feudal labour duties that the reform had not eliminated.

As it turns out, negative judgements fall to ethnic others as well, many of whom are regarded as representatives or collaborators of the foreign regime(s) ruling in Ukraine. Of all the authors, Sarbei is by far the most depreciative in the treatment of non-Ukrainians. Discussing the plight of the Ukrainians in the second half of the $19^{\text {th }}$ century he, for instance, states: "The majority of the landed nobility, and most of all those of Russian or Polish descent, displayed a hostile attitude towards the Ukrainian national idea. (...) The trade sector fell almost completely in the hands of Russians, Jews, Armenians and Greeks, who often did not operate as civilized merchants but as barbaric-predatory wholesale buyers and sellers" Sarbei $(1995$, pp. 105, 108). Similarly, Turchenko's books for the tenth grade present unflattering accounts of above all the Russians living and working in Ukraine. Russian or Russian-speaking officials, for instance, are said to have had a particularly negative attitude towards the Ukrainization campaign in the 1920s, "sabotaging it in all possible ways" 
(Turchenko 1995, p. 194; Turchenko 2001, p. 241). ${ }^{6}$ Moreover, once Ukrainization was revoked by Stalin in the 1930s, Ukrainian-speaking employees in firms headed by Russians were particularly vulnerable to being branded as nationalists, the books argue. Likewise, 'experts' sent from Moscow and Leningrad to assist in the collectivization of agriculture in the 1930s are depicted as ruthless incompetent executioners of the Stalinist regime disregarding local traditions and practices.

Yet, the tone in the newest textbooks has become markedly more tender in relation to the non-Ukrainian groups. In comparison to its predecessor, the new textbook for the ninth grade (Turchenko and Moroko 2001), for instance, is much more careful in its treatment of the Russian and Jewish minorities. Discussing the social position of Ukrainians in comparison to other nationalities in the second half of the $19^{\text {th }}$ century, it provides a neutral description of the economic activities and settlement patterns of Russians and Jews and refrains from using negative qualifications. A similar subtle account is given of the interethnic relations between Ukrainians, Poles and Jews in Western Ukraine under Austrian rule in the beginning of the $20^{\text {th }}$ century. Although the book claims that the majority of Poles were negatively disposed to the Ukrainian liberation struggle, it hails the Ukrainian-Polish compromise of 1914, seeing it as great victory of the Ukrainians and a turning point in Ukrainian-Polish relations. The book also presents a balanced account of the Jews, saying that this minority was initially attracted to the Polish language and culture as that meant access to social domains from which they were previously excluded. However, after the growth of Polish anti-Semitism, the Jews, it is argued, increasingly turned to Zionism and desired to stay neutral in the Polish-Ukrainian conflict. In some cases, Turchenko and Moroko (2001) observe, Jews and Ukrainians cooperated when it was in their mutual interest (they corroborate this claim by mentioning that two Jewish deputies entered the Austrian parliament in 1907 with Ukrainian support). 
Kul'chyts'kyi and Shapoval's (2003) textbook for the $10^{\text {th }}$ grade is also indicative of the more neutral approach to the non-Ukrainian minorities by the newest generation of textbooks. This book addresses national minorities only very briefly and does not specify the national origin of various professional groups (party elite, state officials, intelligentsia, peasants) at all, deflecting attention away from differences between ethnic Ukrainians and ethnic Russians, Jews or other minorities.

\section{Discussion}

Our analysis shows that the textbooks do not consistently depict the Ukrainian nation as either a civic or an ethnic community. On the one hand, an ethnic vision is communicated when the books highlight the importance of language in unifying Ukrainians in Austria and czarist Russia and present maps showing the residential pattern of ethnic Ukrainians.

Likewise, the vilifying of foreign regimes and - to a lesser extent - national minorities are indicative of ethno-cultural notions of nationhood. On the other hand, the books pay far greater attention to the modern period than to pre-modern times and extensively cover social issues. Deep social cleavages are said to have persisted under indigenous Cossack rule and to have divided the nation in the turbulent times of the Russian Revolution and its aftermath. The Bolshevik regime, it is claimed, exploited these divisions by enticing the proletariat and the peasantry with uncompromising populist propaganda and thereby encouraged them to defect from their national group. These elements may be said to point to a civic understanding of nationhood. In sum, the textbooks define the core of the Ukrainian nation ethno-culturally seeing language as the constituent identity marker but nonetheless hold its boundaries to be permeable, with social issues having the potential to compete with national 
loyalties. In addition, a shift seems to be occurring away from exclusively negative appraisals of ethnic others to more neutral descriptions of their attitudes and contributions to Ukrainian society. The only constant in all the textbooks is the negative evaluation of foreign regimes. How can we make sense of this pattern? What does it tell us about the relevance of the theories discussed previously? It can first of all be noted that it does not conform to the classic ethnic-East/civic-West model. This model does not predict a historiography that sees the nation as being dependent on socio-political issues. What could have contributed to the acknowledgement of the contingent nature of national identity? This might first of all be a reflection of the desire among textbook writers to 'tell the truth', i.e. to render a version of history that is as close to historical reality as possible. History textbook writers in Ukraine are typically renowned academics, some of whom were dissidents during the Soviet era while others worked within the confines of Soviet society (Sarbei, Serhienko and Smolyi for instance also wrote Soviet history textbooks). However, regardless of their former political loyalties, all historians were constrained by censorship and the lack and accessibility of sources in Soviet times. Their craving to finally present the historical truth, now that archives have opened up, and for once and for all leave the epoch of ideologically enforced history writing behind should not be underestimated. ${ }^{7}$ In fact, history textbook writers have so enthusiastically introduced new information that they are now criticised by educational practitioners for having produced completely unworkable textbooks containing too much subject matter presented in complicated terminology. ${ }^{8}$ However, the argument that Ukrainian national identity does not operate in a social vacuum may equally well be inspired by a political message after all. The textbook authors may have wanted to warn the Ukrainian authorities that they need to address social issues if they are to prevent foreign powers from exploiting dissatisfaction among the population and subjugating Ukraine to another period of oppressive rule. 
The analysis has also demonstrated a shift from overly hostile depictions of ethnic others, which - as we said - indicates an ethnic understanding of nationhood, to more balanced accounts of their role in Ukrainian society. This is in line with the argument developed by Kuzio that states may start out by promulgating ethnic visions but develop a more civic outlook as they grow older and succeed in consolidating democratic structures. The increasingly moderate tone on national minorities may reflect a growing confidence among policy makers and textbook writers that it is possible to cultivate a strong, more politically oriented, Ukrainian national identity without relying on sharp ethnic boundaries. Alternatively, it may mirror a growing awareness among textbook writers that their products are now open to international scrutiny. Intergovernmental organisations like the Council of Europe and the Organisation for Security and Cooperation in Europe (OSCE) are monitoring European states closely on their policies towards national minorities. A consistent pattern of glorifying the titular nation while denigrating national minorities would almost certainly set off alarm bells at these international watch dogs.

Yet, at the same time, Turchenko's textbooks for the $10^{\text {th }}$ grade have remained very critical of the Russians working and living in Ukraine during the Soviet era. This stance on the Russian minority in combination with an ethnic vision of the Ukrainian nation based on (native) language is not likely to contribute to the identification of the Russian minority (or the Russian-speakers) with the Ukrainian nation. It would appear that the authorities have given priority to a vision of the Ukrainian nation that maximizes distinctiveness vis-à-vis the Russians, taking possible feelings of exclusion from non-ethnic Ukrainians and particularly Russians for granted.

This preference for maximum distinctiveness is understandable from the point of view of providing a justification for Ukrainian statehood. In line with the Wilsonian principle, which until today has remained the leading normative theory of independent statehood, there 
has to be a Ukrainian nation for an independent Ukrainian state to make sense, and what better way of substantiating the claim of distinctiveness than by pointing to a separate language and culture. In fact, justifying Ukrainian statehood clearly is the leitmotiv in the textbooks. All the books have negative judgements on the long periods of foreign domination in Ukraine's past. Foreign rulers are attributed malign intentions and are said to have exploited Ukraine for their own interests. The problems Ukraine faces today, it is argued, have their roots in the past when Ukraine was subjugated to foreign rule. The message of the textbooks is clear: only an independent Ukrainian state can truly represent the interests of the Ukrainian population and can make Ukraine prosper; Ukraine would not have been in the dire straits it is in today if it had been an independent state for centuries.

The question is whether this negative evaluation of foreign rule is going to be the core argument of Ukrainian historiography for years to come. This, I would argue, is unlikely to be the case. It may currently be deemed politically expedient to stress Ukraine's distinctiveness, but as Ukraine grows older and succeeds in developing a stable democratic state political priorities may well change. These changed political circumstances are likely to have an impact on historiography and - related to that - on the way Ukrainian national identity is understood.

\section{Notes}

1. Of all the Soviet nationalities, Ukrainians proved particularly vulnerable for assimilation to the Russian language as their language, Ukrainian, is closely related to Russian and was held in low esteem for well into the $20^{\text {th }}$ century. In fact, many Russians still do not recognise Ukrainian as a distinct language, considering it a simple peasant dialect of Russian. 
2. The division of powers between the central, regional and local levels is formalized by the Education Act of March 1996 (see Vidomosti Verkhovnoi Rady Ukrainy 1996, no 21, pp. 253-279).

3. The attentive reader will have noticed that the references section lists the first generation textbooks in a transcription from Russian and the current generation textbooks in a transcription from Ukrainian. This is because I read the first generation of textbooks in Russian and the current generation in Ukrainian. It is common practice in Ukraine to have Russian translations of the textbooks for Russian-language schools.

4. Each year the Ministry issues a list of officially approved textbooks for all school subjects (see Osvita Ukrainy 2004, no. 60-61, pp. 15-18).

5. A curriculum plan is a detailed guideline for teachers specifying for each lesson the themes that have to be addressed (for the history curriculum plan in use in the 2004-2005 year see Istoria Ukrainy 2001, no. 33-34).

6. Ukrainization is the Ukrainian component of the all-Union Korenizatsia campaign of the Bolsheviks to combat illiteracy and invigorate the languages and cultures of the non-Russian nationalities in the Soviet-Union of the 1920s.

7. In an interview on 13 September 2004 Stanislav Kul'chyt'skyi, one of the authors of the current generation of textbooks, told me that Ukrainian historians are currently feverously researching 'the blank spots' in Ukrainian history.

8. Interview with Olexander Hlushenko, director and history teacher of private lyceum no. 12 in Kiev, on 5 September 2004.

\section{References}


Istoria Ukrainy, 2001, no. 33-34.

Janmaat, J.G. "Identity Construction and Education: The History of Ukraine in Soviet and Post-Soviet Schoolbooks.” In T. Kuzio and P. D’Anieri, eds., Dilemmas of State-Led Nation Building in Ukraine. London: Praeger, 2002.

Kohn, H. The Idea of Nationalism: A Study in its Origins and Background. New York: Macmillan, 1944.

The Age of Nationalism: The First Era of Global History. Westport, CT: Greenwood Press, 1962.

“Western and Eastern Nationalism." In J. Hutchinson and A.D. Smith, eds., Nationalism. Oxford: Oxford University Press, 1994.

Kul'chyts'kyi, S.V. and Y.I. Shapoval. Novitnia Istoria Ukrainy (1914-1939). Kyiv: Heneza, 2003.

Kuzio, T. “"Nationalising States' or Nation-Building? A Critical Review of the Theoretical Literature and Empirical Evidence." Nations and Nationalism, 2001, vol. 7, no. 2, pp. 135-154.

"The Myth of the Civic State: A Critical Survey of Hans Kohn's Framework for Understanding Nationalism.” Ethnic and Racial studies, 2002, vol. 25, no. 1, pp. 20-39. Meincke, F. Cosmopolitanism and the National State. $7^{\text {th }}$ ed., Robert B. Kimber, Translator. Princeton, NJ: Princeton University Press, 1970.

Osvita Ukrainy, 2004, no. 60-61, pp. 15-18.

Phillips, R. History Teaching, Nationhood and the State. London: Cassell, 1998.

Popson, N. "The Ukrainian History Textbook: Introducing Children to the "Ukrainian Nation.” Nationalities Papers, 2001, vol. 29, no. 2, pp. 325-350. 
Prohramy dlia Serednoi Zahal'noosvitn'oi Shkoly: Istoriia Ukrainy 5-11 Klasy; Vsesvitnia Istoriia 6-11 Klasy. Kyiv: Perun, 1996. (Programs for general secondary schools: History of Ukraine 5-11 grade; World History 6-11 grade).

Sarbei, V.H. Istoria Ukrainy: XIX - Nachalo XX Veka. Kyiv: Heneza, 1996.

Serhienko, H.Y. and V.A. Smolyi. Istoria Ukrainy: S Drevneishikh Vremen do Kontsa XVIII Veka. Kyiv: Osvita, 1995.

Shulman, S. "Challenging the Civic/Ethnic and West/East Dichotomies in the Study of Nationalism.” Comparative Political Studies, 2002, vol. 35, no. 5, pp. 554-585.

Shvyd'ko, H.K. Istoria Ukrainy: XVI-XVIII Stolittia. Kyiv: Heneza, 2003,

Smith, A.D. National Identity. London: Penguin, 1991.

Smith, A.D. Nationalism and Modernism. London: Routledge, 1998.

Turchenko, F.H. Noveishaia Istoria Ukrainy: Chast' Pervaia (1917-1945 Gody). Kyiv: Heneza, 1994.

Turchenko, F.H. Novitnia Istoria Ukrainy: Chastyna Persha 1914-1939. Kyiv: Heneza, 2001. Turchenko, F.H. and V.M. Moroko. Istoria Ukrainy: Kinets' XVIII - Pochatok XX Stolittia. Kyiv: Heneza, 2001.

Turchenko, F.H.; P.P. Panchenko and C.M. Tymchenko. Noveishaia Istoria Ukrainy: Chast' Vtoraia (1945-1995 Gody). Kyiv: Heneza, 1995.

Turchenko, F.H.; P.P. Panchenko and C.M. Tymchenko. Novitnia Istoria Ukrainy: Chastyna Druha 1939-2001. Kyiv: Heneza, 2001.

Vidomosti Verkhovnoi Rady Ukrainy, 1996, no 21, pp. 253-279. (This is the official periodical of the Ukrainian parliament which publishes all government and parliament decisions). 
Wiborg, S. "Political and Cultural Nationalism in Education. The Ideas of Rousseau and Herder Concerning National Education." Comparative Education, 2000, vol. 36, no. 2, pp. $235-243$. 